\title{
Inter-specific differences in the structure and mechanics but not the chemical composition of antlers in three deer species
}

\author{
Francisco Ceacero ${ }^{1,2, *}$, Jan Pluháček ${ }^{2,3}$, Tomás Landete-Castillejos ${ }^{4,5,6}$, \\ Andrés J. García ${ }^{4,5,6}$ \& Laureano Gallego $0^{4,5,6}$
}

1) Department of Animal Science and Food Processing, Faculty of Tropical AgriSciences, Czech University of Life Sciences, Kamýcká 129, CZ-165 00, Prague 6 - Suchdol, Czech Republic ( ${ }^{*}$ corresponding author's e-mail: ceacero@ftz.czu.cz)

2) Department of Ethology. Institute of Animal Science, Prátelství 815, CZ-104 01 Prague Uhřiněves, Czech Republic

3) Ostrava Zoo, Michálkovická 197, CZ-710 00 Ostrava, Czech Republic

4) Sección de Recursos Cinegéticos y Ganaderos, Instituto de Desarrollo Regional (IDR), Universidad de Castilla-La Mancha (UCLM), ES-02071 Albacete, Spain

5) Instituto de Investigación en Recursos Cinegéticos (IREC), Consejo Superior de Investigaciones Científicas, Universidad de Castilla-La Mancha, Junta de Comunidades de Castilla-La Mancha (CSIC-UCLM-JCCM), Ronda de Toledo s/n, ES-13071 Ciudad Real, Spain

6) Departamento de Ciencia y Tecnología Agroforestal y Genética, ETSIA, Universidad de Castilla-La Mancha (UCLM), ES-02071 Albacete, Spain

Received 5 Apr. 2015, final version received 30 June 2015, accepted 14 Aug. 2015

Ceacero, F., Pluháček, J., Landete-Castillejos, T., García, A. J. \& Gallego, L. 2015: Inter-specific differences in the structure and mechanics but not the chemical composition of antlers in three deer species. - Ann. Zool. Fennici 52: 368-376.

Antlers are costly structures produced annually by male cervids using minerals obtained from their diet and from resorption of their skeleton. Availability and nutritive quality of food resources therefore have a great impact on the investment of males in these secondary sexual traits. We studied the structure, mineral composition and mechanical quality of antlers of the Siberian wapiti (Cervus canadensis sibiricus), Père David's deer (Elaphurus davidianus) and Vietnamese sika deer (Cervus nippon pseudaxis), three closely-related cervid species. The three herds investigated were maintained under the same feeding and management conditions (one male per herd) throughout a 3-year study period. We showed that there was no significant inter-specific difference in antler composition of the three species under the same feeding regime. However, mechanical properties varied between the Siberian wapiti and the other two species; and structural characteristics were different among all of them. Our results show that antler composition has a similar chemical profile across species when grown under the same feeding regime whereas the internal structure and mechanical properties appear to be species dependent. 


\section{Introduction}

According to prevailing theories on costly secondary sexual characteristics, such as antlers, these structures are believed to indicate quality of the male, and thus are likely to reflect body condition and food intake (Harvey \& Bradbury 1991; in deer antlers: Ditchkoff et al. 2001, Weladji et al. 2005). The rate of mineralization of antlers is faster than in any other animal tissue (Wolfe 1982, Gómez et al. 2013). Antlers are cast every year, even if they constitute up to an astonishing 35\% of the skeleton weight of adult red deer (Cervus elaphus: 24\% mean value; Gómez et al. 2012).

Two important findings are common to a series of recent studies on red deer. First, antler characteristics reflect the physiological effort invested in their growth. There are differences between the top and burr in cortical thickness, chemical composition (Landete-Castillejos et al. 2007a, 2007b), mechanical properties (Landete-Castillejos et al. 2007c), and even in histological parameters such as porosity and structure (Landete-Castillejos et al. 2013). Second, antler characteristics vary between deer populations differing in nutrition and management, with the chemical composition of the antler reflecting that of diet (Landete-Castillejos et al. 2007b, 2013, Estevez et al. 2009). This also affects both mechanical properties and histology (Landete-Castillejos et al. 2007b, 2013). However, few studies that have compared these properties and the relationships between deer species (Kitchener 1991, Blob \& LaBarbera 2001, Pathak et al. 2001, Blob \& Snelgrove 2006) have produced unclear results, most probably due to the antlers being of very different origins. Thus, it is yet to be discerned if, under the same feeding regime, different species grow antlers with similar internal structure, chemical composition and mechanical properties. The aim of this study was therefore to compare the antler characteristics of three deer species reared under similar nutritional and housing conditions.

\section{Material and methods}

\section{Collection of samples}

We collected antlers from three closely-re- lated cervid species (Hernandez-Fernandez \& Vrba 2005) kept captive in Ostrava Zoo (Czech Republic): Siberian wapiti or Altai maral (Cervus canadensis sibiricus), Vietnamese sika deer (Cervus nippon pseudaxis), and Père David's deer (Elaphurus davidianus). The zoo is located in a large forested area in the center of the city. Each species was kept all year round in outdoor enclosures of the following sizes: $2200 \mathrm{~m}^{2}$ for Vietnamese sika deer, $3000 \mathrm{~m}^{2}$ for Père David's deer, and $4800 \mathrm{~m}^{2}$ for Siberian wapiti. Siberian wapiti were introduced to the zoo in 1961 when one male and two females were imported from the Soviet Union. A pair of Père David's deer was brought in from Leipzig Zoo (Germany) in 1974; and one male and three females of Vietnamese sika deer were introduced from Kronberg Zoo and Tierpark Berlin (both in Germany) in 1993. Since the establishment of the herds, all three species have bred regularly and most of the calves have been exported to other holders. During the period of this research (2010-2012), each of the three herds was composed of one breeding male (the same males throughout the study period), three to five hinds and their calves. The herds were kept under similar conditions during the study period, including having a similar diet based on grass (summer) and hay (winter), both available ad libitum. Each animal also received $1.2 \mathrm{~kg}$ (Siberian wapiti and Père David's deer) or $0.4 \mathrm{~kg}$ (Vietnamese sika deer) of pellets per day (see composition in Table 1), and the same amount of oats. During winter, $2 \mathrm{~kg}$ (Siberian wapiti and Père David's deer) or $0.5 \mathrm{~kg}$ (Vietnamese sika deer) of beet was additionally provided daily per animal. At least two feeders for hay were available in each enclosure, and the number of feeders for pellets and oats matched the number of adult animals so no adult individual had limited access to food (Ceacero et al. 2012). One pure-salt block was also always present in each enclosure. The keepers remained the same during the study period.

Previous studies have shown that numerous factors affect antler growth and properties (reviewed by Landete-Castillejos et al. 2012). For our comparative study it was necessary to have similar conditions throughout the study (e.g. stable social environment, housing conditions and feeding regimes, same adult male, 


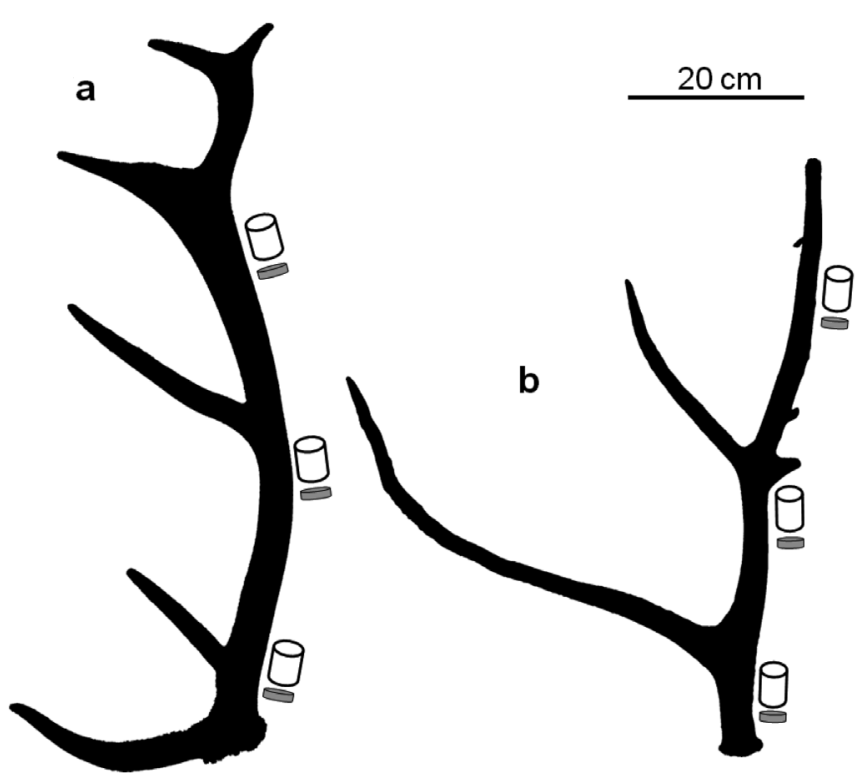

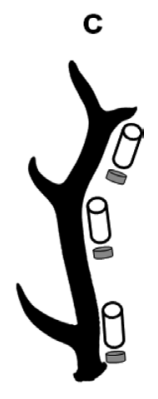

Fig. 1. Scheme of the studied material. Sample levels from the proximal, middle and distal portions of the antler in the three species: (a) Cervus canadensis sibiricus, (b) Elaphurus davidianus and (c) Cervus nippon pseudaxis. same locality, lack of diseases, etc.). As a result of these requirements, size was limited but comparable data necessary for such a study could be gathered.

\section{Analytical procedures}

Antlers grown during each of the studied seasons were collected after casting and sampled at three positions (proximal, middle and distal portions; Fig. 1): 6-cm-long cross-sectional pieces were cut from each level. The slices were colored with a 1:4 ink:water solution (Pelikan ink 4001, Germany) and dried for $24 \mathrm{~h}$ at room temperature (Bubenik 1990). The slices were then polished to increase the contrast between the cortical and trabecular bones. Finally, the basal transverse cross-sections were scanned (HP ScanJet 4370 Photo Scanner) at $400 \mathrm{dpi}$. The following macroscopic variables were measured with the ImageJ (National Institute of Health, USA) image analysis software: (1) cortical bone thickness (CBT) of the cross-sections (the mean value of six equally spaced measurements); (2) total diameter (the mean of three equally spaced measurements); (3) proportion of the diameter occupied by the cortical bone (CBD\%; calculated from the previous two measurements); (4) total area of the cross-section; and (5) area occupied by the cor- tical bone expressed as a percentage (CBA\%). $\mathrm{CBT}, \mathrm{CBD} \%$ and $\mathrm{CBA} \%$ were used as measures to define bone structure of the antler.

From each sampling level, two rectangular bars of pure cortical bone $(50 \times 2.5 \times 4 \mathrm{~mm})$ were extracted from the internal side and longitudinal axis of the antler and prepared for mechanical testing. Each piece was initially cut longitudinally into $60 \mathrm{~mm}$ long, $4 \mathrm{~mm}$ deep and $5 \mathrm{~mm}$ wide strips using a low-speed petrographic saw and then polished with no. 400 and 1000

Table 1. Composition of pellets (as dry matter) provided to deer during the three-year study period.

\begin{tabular}{lr}
\hline Nutrient & Content \\
\hline Crude protein (\%) & 15.6 \\
lysin $\left(\mathrm{g} \mathrm{kg}^{-1}\right)$ & 6.9 \\
methionin $\left(\mathrm{g} \mathrm{kg}^{-1}\right)$ & 2.3 \\
Crude fat $(\%)$ & 2.8 \\
Crude fibre $(\%)$ & 12.7 \\
Ash $(\%)$ & 8.7 \\
calcium $\left(\mathrm{Ca}, \mathrm{g} \mathrm{kg}^{-1}\right)$ & 6.7 \\
sodium $\left(\mathrm{Na}, \mathrm{g} \mathrm{kg}^{-1}\right)$ & 1.7 \\
potassium $\left(\mathrm{K}_{\mathrm{g} \mathrm{kg}}^{-1}\right)$ & 1.0 \\
phosphorus $\left(\mathrm{P}, \mathrm{g} \mathrm{kg}^{-1}\right)$ & 4.6 \\
iron $(\mathrm{Fe}, \mathrm{mg} \mathrm{kg})$ & 185.0 \\
zinc $\left(\mathrm{Zn}, \mathrm{mg} \mathrm{kg}^{-1}\right)$ & 110.0 \\
manganese $\left(\mathrm{Mn}^{-1} \mathrm{mg} \mathrm{kg}^{-1}\right)$ & 87.0 \\
copper $\left(\mathrm{Cu}, \mathrm{mg} \mathrm{kg}^{-1}\right)$ & 14.0 \\
selenium $\left(\mathrm{Se}, \mathrm{mg} \mathrm{kg}^{-1}\right)$ & 0.31 \\
\hline
\end{tabular}


sandpaper using semiautomatic equipment (Struers LaboPol-21, Ballerup, Denmark). During preparation, the samples were kept moist to avoid overheating and care was taken to produce parallel surfaces. The width and depth of each sample were recorded to the nearest $0.01 \mathrm{~mm}$ using a digital caliper. Tests were carried out with the periosteal side in tension (Currey et al. 2009). During the period of active fighting, antlers have a moisture content similar to samples left at 'dry room' conditions and so mechanical testing was conducted at near dry conditions (Currey et al. 2009). In order to ensure a homogeneous humidity content, the samples were first hydrated in Hank's balanced buffer solution (HBSS BE10527F; Lonza, Verviers, Belgium) for $48 \mathrm{~h}$, and then left to dry at room temperature $\left(20^{\circ} \mathrm{C}\right)$ and humidity (40\%) for another $48 \mathrm{~h}$ before testing.

The two sample bars were used in two types of mechanical analyses: quasi static bending tests and impact tests. Quasi static bending tests were carried out in a Z005 ProLine $500 \mathrm{~N}$ materials testing machine (Zwick, Ulm, Germany) for three-point bending measurement. The gauge length was set at $40 \mathrm{~mm}$ to minimize shear forces (Spatz et al. 1996), and the head speed at $32 \mathrm{~mm} \mathrm{~min}{ }^{-1}$. This test was used to calculate Young's modulus of elasticity $(E)$, bending strength (BS; maximum stress at the greatest load borne), and work-to-peak force ( $W$; total work under the load-deformation curve up to the maximum load borne, divided by the cross-sectional area). Total work standardized in this way provides an estimate of the toughness of the specimen. The impact testing procedure is based on a pendulum falling and breaking an unnotched sample whilst the periosteal side is in tension. The loss of kinetic energy of the pendulum is measured and is taken to be the energy required to break the sample. This energy is normalized by dividing by the cross-sectional area of the specimen, producing impact energy absorption or impact work $(U)$. Tests were carried out using a CEAST-IMACTOR II testing machine (CEAST S.p.A., Pianezza, Italy) with a manual releasing device and the hammer exercising $1 \mathrm{~J}$ of energy.

After the impact test, one of the sample halves was weighed on a Precision DT-510 balance (Gram, Barcelona, Spain), and used to calculate Cortical Bone Density by dividing the weight of the dry samples by their volume (length $\times$ width $\times$ depth). In order to avoid volatilization of some of the minerals, the specimens were dried in an oven at $60{ }^{\circ} \mathrm{C}$ for $72 \mathrm{~h}$ (DigiHeat, Barcelona, Spain). After being dried using the same procedure, the other half of the sample was weighed and acid-digested in $\mathrm{HNO}_{3}$ and $\mathrm{H}_{2} \mathrm{O}_{2}$ in a microwave (Milestone, Sorisole, Italy) and the chemical composition determined by optical emission spectroscopy (ICAP 6500 DUO Spectrometer/IRIS INTREPID II XDL; Thermo Scientific, Asheville, USA). These analyses were conducted by the Service of Ionomic at the CEBAS Agronomic Institute (CISC; Murcia, Spain). We quantified the concentration of macrominerals: $\mathrm{Ca}, \mathrm{P}, \mathrm{Mg}, \mathrm{Na}, \mathrm{K}$; and the main microminerals: $\mathrm{S}, \mathrm{Sr}, \mathrm{Zn}, \mathrm{Mn}, \mathrm{Fe}$, $\mathrm{B}$ and $\mathrm{Cu}$.

\section{Statistical analyses}

Mann-Whitney $U$-test was used to test differences in structure, mechanical properties and chemical composition between the distal and proximal samples. Differences among species (pooling results obtained for the three studied positions in each antler) were tested with Kruskal-Wallis ANOVA. Finally, General Linear Mixed Models, with antler as the subject and position as the repeated measure evaluate the influence of species and year. Analyses were performed using IBM ${ }^{\circledR}$ SPSS $^{\circledR}$ Statistics ver. 20.

\section{Results}

The distal and proximal portions of the studied antlers differed only in their CBT (Mann-Whitney $U$-test: $U=-3.046 ; p=0.001)$ and $\mathrm{Na}$ content $(U=-2.340 ; p=0.019)$, indicating that during the whole study period nutrition was adequate, and the animals were in good overall condition to grow high-quality antlers (see the internal structure at the three studied levels in Fig. 2). Extensive differences would indicate exhaustion or inadequate nutrition during antler growth (Landete-Castillejos et al. 2012).

The structural characteristics, mechanical properties and chemical composition of the studied antlers (the three positions pooled) are 
a



b

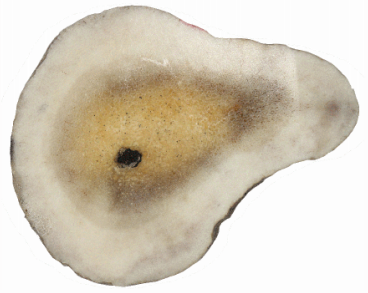

C

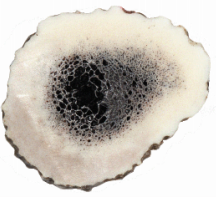


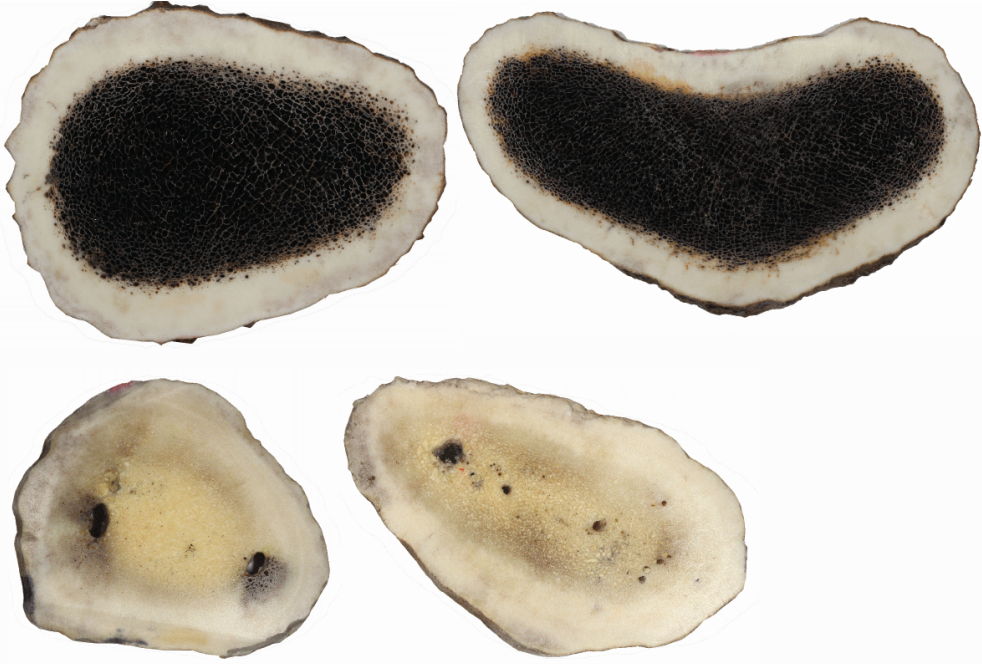

d



Fig. 2. Internal structure of transverse slices of antlers of (a) Cervus canadensis sibiricus, (b) Elaphurus davidianus and (c) Cervus nippon pseudaxis at the three studied levels (from left to right: proximal, middle and distal portions; see Fig. 1). Higher resolution details of the structure from the cortical layer to the core of the antler are shown in $\mathbf{d}$ (species as in a-c shown from top to bottom).

summarized in Table 2. Kruskal-Wallis ANOVA revealed inter-specific differences in all the structural and mechanical properties of the antler, but only few differences in the chemical composition: just in ash content and a few microminerals (Table 2).

Finally, GLM revealed inter-specific differences (but fewer inter-year differences) in most of the structural and mechanical properties: CBT (species: $p=0.001$ ), CBD\% (species: $p<0.001$ ), CBA\% (species: $p<0.001$ ), Cortical Bone Density (species: $p<0.001), E$ (species: $p<0.001$; year: $p=0.044$ ), BS (species: $p<0.001$ ), $W$ (species: $p<0.001$, year: $p=0.038$ ), $U$ (species: $p=0.011$ ), Ash (species: $p<0.001$, year: $p=$ 0.001 ); and some minerals, especially microminerals: $\mathrm{P}$ (species: $p=0.045), \mathrm{Mg}$ (species: $p<$ 0.001), $\mathrm{Na}$ (species: $p=0.006), \mathrm{B}$ (species: $p=$ 0.001), Mg (species: $p<0.001)$, Mn (species: $p$ $<0.001$ ), Sr (year: $p=0.002$, species: $p<0.001$ ), Zn (species: $p<0.002$ ).

\section{Discussion}

The comparison of antler characteristics suggests that while there are clear differences among species in the internal structure and mechanical quality of the bone material, the chemistry is basically the same, at least for the most important macrominerals. Even if small inter-year differences were found, probably due to uncontrollable variability in the mineral content of the food (food supplements and suppliers were the same throughout the study period), these were reflected in the antlers of the three species in the same way, and thus, we found inter-year differences in only a few micro-minerals, which may be considered species-related. This shows that the same diet offered to different cervid species leads to a similar chemical composition of the antlers. Nevertheless, even with almost identical constituents, antlers of each species have their own internal structure and mechanical 
properties. Previous studies have shown that the chemical make-up of antlers reflects nutrition (Landete-Castillejos et al. 2007b, Estevez et al. 2009), and even differences in antler composition and mechanical properties between years within the same population can be explained by changes in the mineral content of the diet (Landete-Castillejos et al. 2010). We found a slight variation in the chemical composition of antlers across the three studied years; however, the trend was the same in all species leading to the absence of inter-specific differences. This way, we can confirm that antlers grown under similar nutritional regimes will have similar chemical composition, even if grown by different species.

However, the studied species differed in tested mechanical properties and structural characteristics of the antler bone material. In particular, the Siberian wapiti (Cervus canadensis sibiricus) differed from the two remaining species, which in turn did not differ much from each other (Table 2). The fact that antlers of the Vietnamese sika deer (C. nippon pseudaxis) are structurally and mechanically more similar to those of Père David's deer (Elaphurus davidianus) than to those of the Siberian wapiti does not suggest that those characteristics are related to phylogeny (Hernandez-Fernandez \& Vrba 2005), even if closely related species frequently show similarities in the basic external structure of the antler (Lincoln, 1992). It seems easier to explain why some of these variables co-vary together than to explain why these differences among species appeared. Mineral content is the main determinant of the mechanical properties of antlers (Currey 1979). The ash content in the antlers of the Vietnamese sika and Père David's deer was higher than in the Siberian wapiti's antlers, which correlates with bending strength

Table 2. Structural, mechanical and chemical profiles of antlers from three cervid species. All the studied antlers were grown in the same zoological garden (Ostrava, Czech Republic) under similar feeding and housing conditions. Presented values are means with their SDs; $p$ values are from Kruskal-Wallis ANOVA; different letters in superscript indicate significant differences between groups (Dunn-Bonferroni post-hoc test).

\begin{tabular}{|c|c|c|c|c|}
\hline & $\begin{array}{c}\text { Cervus canadensis } \\
\text { sibiricus }\end{array}$ & $\begin{array}{l}\text { C. nippon } \\
\text { pseudaxis }\end{array}$ & Elaphurus davidianus & $p$ \\
\hline \multicolumn{5}{|l|}{ Structural characteristics } \\
\hline \multicolumn{5}{|l|}{ Cortical bone } \\
\hline thickness (mm) & $7.44 \pm 1.31^{\mathrm{a}}$ & $5.31 \pm 0.73^{b}$ & $6.48 \pm 1.37^{\mathrm{ab}}$ & 0.005 \\
\hline diameter (\%) & $28.7 \pm 6.1^{b}$ & $45.5 \pm 3.6^{a}$ & $36.8 \pm 4.0^{\mathrm{b}}$ & $<0.001$ \\
\hline area $(\%)$ & $48.9 \pm 6.5^{b}$ & $69.5 \pm 3.7^{a}$ & $64.2 \pm 10.0^{\mathrm{a}}$ & $<0.001$ \\
\hline density $\left(\mathrm{kg} \mathrm{dm}^{-3}\right)$ & $1.693 \pm 0.034^{b}$ & $1.765 \pm 0.040^{\mathrm{a}}$ & $1.718 \pm 0.042^{\mathrm{ab}}$ & 0.008 \\
\hline \multicolumn{5}{|l|}{ Mechanical properties } \\
\hline Young's modulus at $10 \mathrm{~N}(\mathrm{GPa})$ & $23.9 \pm 1.7^{\mathrm{b}}$ & $27.7 \pm 2.4^{\mathrm{a}}$ & $28.4 \pm 2.7^{a}$ & 0.003 \\
\hline Bending strength (MPa) & $299 \pm 22^{b}$ & $336 \pm 21^{a}$ & $338 \pm 23^{a}$ & 0.004 \\
\hline Work to maximum load $\left(\mathrm{kJ} \mathrm{m}^{-2}\right)$ & $43.7 \pm 4.8^{\mathrm{a}}$ & $35.4 \pm 4.2^{\mathrm{b}}$ & $37.4 \pm 5.3^{\mathrm{ab}}$ & 0.008 \\
\hline Impact work (kJ m²) & $19.6 \pm 3.8^{a}$ & $16.2 \pm 3.9^{a b}$ & $14.9 \pm 2.1^{\mathrm{b}}$ & 0.030 \\
\hline \multicolumn{5}{|l|}{ Chemical composition } \\
\hline Ash (\%) & $60.8 \pm 0.5^{\mathrm{b}}$ & $62.7 \pm 0.7^{a}$ & $62.7 \pm 0.7^{a}$ & $<0.001$ \\
\hline $\mathrm{Ca}(\%)$ & $20.2 \pm 1.0$ & $21.1 \pm 0.5$ & $20.5 \pm 1.9$ & \\
\hline $\mathrm{P}(\%)$ & $10.4 \pm 0.5^{b}$ & $10.9 \pm 0.2^{\mathrm{a}}$ & $10.7 \pm 0.9^{a b}$ & 0.014 \\
\hline $\operatorname{Mg}(\%)$ & $0.379 \pm 0.026^{b}$ & $0.433 \pm 0.017^{a}$ & $0.407 \pm 0.032^{\mathrm{ab}}$ & $<0.001$ \\
\hline $\mathrm{Na}(\%)$ & $0.554 \pm 0.036$ & $0.546 \pm 0.022$ & $0.563 \pm 0.050$ & \\
\hline $\mathrm{K}\left(\mathrm{mg} \mathrm{kg}^{-1}\right)$ & $256 \pm 18$ & $260 \pm 35$ & $270 \pm 22$ & \\
\hline $\mathrm{S}\left(\mathrm{mg} \mathrm{kg}^{-1}\right)$ & $2451 \pm 121$ & $2530 \pm 69$ & $2501 \pm 194$ & \\
\hline $\mathrm{Sr}\left(\mathrm{mg} \mathrm{kg}^{-1}\right)$ & $122 \pm 9^{a}$ & $115 \pm 4^{a}$ & $101 \pm 9^{b}$ & $<0.001$ \\
\hline $\mathrm{Zn}\left(\mathrm{mg} \mathrm{kg}{ }^{-1}\right)$ & $83.9 \pm 6.9^{a}$ & $61.0 \pm 4.5^{b}$ & $64.0 \pm 4.7^{b}$ & $<0.001$ \\
\hline $\mathrm{Mn}\left(\mathrm{mg} \mathrm{kg}^{-1}\right)$ & $15.9 \pm 0.9^{b}$ & $18.0 \pm 0.7^{a}$ & $17.1 \pm 1.1^{\mathrm{ab}}$ & $<0.001$ \\
\hline $\mathrm{Fe}\left(\mathrm{mg} \mathrm{kg}^{-1}\right)$ & $6.92 \pm 4.38$ & $4.49 \pm 2.93$ & $5.60 \pm 2.27$ & \\
\hline $\mathrm{B}\left(\mathrm{mg} \mathrm{kg}^{-1}\right)$ & $0.75 \pm 0.12^{b}$ & $1.09 \pm 0.35^{a}$ & $0.63 \pm 0.18^{b}$ & 0.001 \\
\hline $\mathrm{Cu}\left(\mathrm{mg} \mathrm{kg}^{-1}\right)$ & $0.75 \pm 0.86$ & $0.36 \pm 0.10$ & $0.36 \pm 0.10$ & \\
\hline
\end{tabular}


and stiffness (Currey et al. 2009), also being higher in those two species. In contrast, the lower work-to-maximum load and impact work can be explained because the greater the ash content, the lower the protein content (mainly collagen), and a higher protein content results in a greater work-to-maximum load and impact work (Currey et al. 2009). Greater ash content also explains the higher Cortical Bone Density in antlers of the Vietnamese sika and Père David's deer. Finally, both the $\mathrm{CBD} \%$ and $\mathrm{CBA} \%$ showed a greater expenditure in creating a thick cortical layer. This probably means that males of those species had an increased opportunity to fully mineralize their cortical antler, which explained not only the greater content of ash, but also the fact that they had lower concentrations of zinc. This element has been found in more significant amounts in deer with less mineralized antlers (Landete-Castillejos et al. 2007b), which also show not-fully-closed osteons (the fundamental functional unit of cortical bone that possess a tubular structure) (Gomez et al. 2013, Landete-Castillejos et al. 2013). In contrast, Zn is completely depleted upon full mineralization (Landete-Castillejos et al. 2013). One possibility is that due to their greater size, the Siberian wapiti may require a proportionally smaller amount of food to satisfy their energy and protein demand; thus, they may need food richer in elements to fully mineralize their antlers to reach values similar to those of the other two species. However, contrary to our results, when comparing three tropical deer species, Pathak et al. (2001) found that it was the smallest species that had the lowest ash content $(60.3 \%$ in Axis porcinus vs. $62.5 \%$ in A. axis and $62.9 \%$ in Rucervus duvaucelii). Other explanations may be related to evolutionary (but not adaptive) constraints, as proposed by Blob and LaBarbera (2001); or to the existence of adaptive constraints based on the quadratic body mass-antler allometry found in cervids (Lemaître et al. 2014; larger antlers would have similar mechanical properties with smaller expenditure in minerals).

Few studies attempted to investigate inter-specific differences in antler traits (Kitchener 1991, Blob \& LaBarbera 2001, Pathak et al. 2001, Blob \& Snelgrove 2006). Chen et al. (2009) recently summarized the limited published data on the mechanical properties of antlers of 11 species, and Blob and Snelgrove (2006) compared published data on antler stiffness among the Odocoileini. However, those data are unfortunately not particularly comparable due to different methodologies, the unknown or heterogeneous origin of the animals, the lack of details as to which part of the antler was used, and often a small sample size (in some cases just one antler). As an example, the coefficient of variation (CV) for the data shown by Blob and Snelgrove (2006) for $E$ is $40.6 \%$ ( 9 species). Similarly, CVs for the summarized data shown by Chen et al. (2009) were $39.9 \%$ for $E$ (16 species), $34.7 \%$ for BS (6 species), $61.8 \%$ for $W$ (10 species), $26.2 \%$ for Cortical Bone Density (10 species), and $11.2 \%$ for Ash (8 species). In our study, however, respective CVs were $9.1 \%$, $6.8 \%, 11.8 \%, 2.2 \%$ and $1.7 \%$. Only Pathak et al. (2001) found a similarly small CV when studying three captive tropical deer species $(2.3 \%$ for ash, akin to our study). This highlights that only standardized studies under controlled conditions can reliably demonstrate inter-specific differences in antler properties. In particular, zoos keeping various deer species under the same living conditions and management provide excellent material for such inter-specific studies (Gauthier \& Barrette 1985, Ralls et al. 1986, Pluháček et al. 2012, 2014).

\section{Conclusions}

From our study of three cervid species; the Siberian wapiti (Cervus canadensis sibiricus), Père David's deer (Elaphurus davidianus), and the Vietnamese sika deer (Cervus nippon pseudaxis), we conclude that the variation among species in antler characteristics indicates the effects of nutrition in determining the mineral composition in a similar way across species. However, internal structure and mechanical properties seem to be species-specific.

\section{Acknowledgements}

This paper was funded by projects AGL2012-38898 (Ministry of Economy and Competitiveness, Spain), 
CIGA20145001 (Czech University of Life Sciences, Czech Republic), IGA20155013 (Faculty of Tropical AgriSciences, Czech University of Life Sciences, Czech Republic) and MZERO0714 (Ministry of Agriculture, Czech Republic). Our thanks are due to our colleagues from Ostrava Zoo, namely Michal Šafrán, Hana Tomková, and Rudolf Mikulský. Jamil Cappeli assisted in the preparation of Fig. 2. Finally, we would like to thank the two anonymous reviewers and the editor for their valuable comments and suggestions to improve the manuscript.

\section{References}

Blob, R. W. \& LaBarbera, M. 2001: Correlates of variation in deer antler stiffness: age, mineral content, intra-antler location, habitat, and phylogeny. - Biological Journal of the Linnean Society 74: 113-120.

Blob, R. W. \& Snelgrove, J. M. 2006: Antler stiffness in moose (Alces alces): correlated evolution of bone function and material properties? - Journal of Morphology 267: 1075-1086.

Bubenik, G. A. 1990: The antler as a model in biomedical research. - In: Bubenik, G. A. \& Bubenik, A. B. (eds.), Horns, pronghorns and antlers. Evolution, morphology, physiology and social significance: 474-489. Springer, New York, USA.

Ceacero, F., García, A. J., Landete-Castillejos, T., Bartošová, J., Bartoš, L. \& Gallego, L. 2012: Benefits for dominant red deer hinds under a competitive feeding system: food access behavior, diet and nutrient selection. - PLOS ONE 7: e32780, doi:10.1371/journal.pone.0032780.

Chen, P. Y., Stokes, A. G. \& McKittrick, J. 2009: Comparison of the structure and mechanical properties of bovine femur bone and antler of the North American elk (Cervus elaphus canadensis). - Acta Biomaterialia 5: 693-706.

Currey, J. D. 1979: Mechanical properties of bone tissues with greatly differing functions. - Journal of Biomechanics 12: 313-319.

Currey, J. D., Landete-Castillejos, T., Estévez, J., Ceacero, F., Olguín, A., García, A. \& Gallego, L. 2009: The mechanical properties of deer antler bone when used in fighting. - Journal of Experimental Biology 212: 3985-3993.

Ditchkoff, S. S., Lochmiller, R. L., Masters, R. E., Hoofer, S. R. \& van den Busshe, R. A. 2001: Major-histocompatibility-complex-associated variation in secondary sexual traits of white-tailed deer (Odoicoleus virginianus): evidence for good-genes advertisement. - Evolution 55: 616-625.

Harvey, P. H. \& Bradbury, J. W. 1991: Sexual selection. In: Krebs, J. R. \& Davies, N. B. (eds.), Behavioural ecology: an evolutionary approach: 203-233. Blackwell Scientific Publications, Oxford, UK.

Estévez, J. A., Landete-Castillejos, T., Martínez, A., García, A. J., Ceacero, F., Gaspar-López, E., Calatayud, A. \& Gallego, L. 2009: Antler mineral composition of Iberian red deer (Cervus elaphus hispanicus) is related to mineral profile of diet. - Acta Theriologica 54: 235-242.

Gauthier, D. \& Barrette, C. 1985: Suckling and weaning in captive white tailed and fallow deer. - Behaviour 94 : 128-149.

Gómez, S., Garcia, A. J., Luna, S., Kierdorf, U., Kierdorf, H., Gallego, L. \& Landete-Castillejos, T. 2013: Labeling studies on cortical bone formation in the antlers of red deer (Cervus elaphus). - Bone 52: 506-515.

Gómez, J. A., Ceacero, F., Landete-Castillejos, T., Gaspar-López, E., García, A. J. \& Gallego, L. 2012: Factors affecting antler investment in Iberian red deer. Animal Production Science 52: 867-873.

Hernandez-Fernandez, M. \& Vrba, E. S. 2005: A complete estimate of the phylogenetic relationships in Ruminantia: a dated species-level supertree of the extant ruminants. - Biological Reviews 80: 269-302.

Kitchener, A. C. 2000: Fighting and the mechanical design of horns and antlers. - In: Domenici, P. \& Blake, R. W. (eds.), Biomechanics in animal behaviour: 229-253. BIOS Scientific Publishing, Oxford, UK.

Landete-Castillejos, T., García, A.J. \& Gallego L. 2007a: Body weight, early growth and antler size influence antler bone mineral composition of Iberian red deer (Cervus elaphus hispanicus). - Bone 40: 230-235.

Landete-Castillejos, T., Estévez, J. A., Martínez, A., Ceacero, F., García, A. J. \& Gallego, L. 2007b: Does chemical composition of antler bone reflect the physiological effort made to grow it? - Bone 40: 1095-1102.

Landete-Castillejos, T., Currey, J. D., Estevez, J. A., Gaspar-López, E., García, A. J. \& Gallego, L. 2007c: Influence of physiological effort of growth and chemical composition on antler bone mechanical properties. Bone 41: 794-803.

Landete-Castillejos, T., Currey, J. D., Estevez, J. A., Fierro, Y., Calatayud, A., Ceacero, F., Garcia, A. J. \& Gallego, L. 2010: Do drastic weather effects on diet influence changes in chemical composition, mechanical properties and structure in deer antlers? - Bone 47: 815-825.

Landete-Castillejos, T., Estévez, J. A., Ceacero, F., García, A. J. \& Gallego, L. 2012: A review of physiological effort, nutrition, and ecological conditions on mineral composition, mechanical properties and internal structure of antlers. - Frontiers in Bioscience E4: 2328-2339.

Landete-Castillejos, T., Currey, J. D., Ceacero, F., Garcia, A. J., Gallego, L. \& Gómez, S. 2012: Does nutrition affect bone porosity and mineral tissue distribution in deer antlers? The relationship between histology, mechanical properties and mineral composition. - Bone 50: 245-254.

Landete-Castillejos, T., Estevez, J. A., Ceacero, F., Garcia, A. J. \& Gallego, L. 2013: Effects of public vs. private management on deer antler composition, mechanical and structural variables. - European Journal of Wildlife Research 59: 519-529.

Lemaître, J. F., Vanpé, C., Plard, F. \& Gaillard, J. M. 2014: The allometry between secondary sexual traits and body size is nonlinear among Cervids. - Biology Letters 10: 20130869, doi:10.1098/rsbl.2013.0869.

Lincoln, G. A. 1992: The biology of antlers. - Journal of Zoology 226: 517-728.

Pathak, N. N., Pattanaik, A. K., Patra, R. C. \& Arora, B. M. 2001: Mineral composition of antlers of three deer species reared in captivity. - Small Ruminant Research 
42: 61-65.

Pluháček, J., Olléová, M., Bartošová, J. \& Bartoš, L. 2012: Effect of ecological adaptation on suckling behaviour in three zebra species. - Behaviour 149: 1395-1411.

Pluháček, J., Olléová, M., Bartoš, L. \& Bartošová, J. 2014: Time spent suckling is affected by different social organization in three zebra species. Journal of Zoology 292: 10-17.

Ralls, K., Kranz, K. \& Lundrigan, B. 1986: Mother-young relationships in captive ungulates: variability and clustering. - Animal Behaviour 34: 134-145.

Spatz, H. Ch., O'Leary, E. J. \& Vincent, J. F. V. 1996:
Young's moduli and shear moduli in cortical bone. Proceedings of the Royal Society of London B 263: 287-294.

Weladji, R. B., Holand, Ø., Steinheim, G., Colman, J. E., Gjostein, H. \& Kosmo, A. 2005: Sexual dimorphism and intercorhort variation in reindeer calf antler length is associated with density and weather. - Oecologia 145: 549-555.

Wolfe, G. J. 1982: The relationship between age and antler development in wapiti. - In: Brown, R. D. (ed.), Antler development in Cervidae: 29-36. Caesar Kleberg Wildlife Research Institute, Kingsville, USA. 